\title{
Poemas
}

\author{
Daniela Lázaro*
}

\section{DESPEDIDA DE REMEDIOS}

De rojo cuece las paredes

la noche

las paredes de una esquina

las paredes de una fuente de ladrillos

que deja

caer

un umbral por cada vez que alguien dice adiós

En los oídos de él

resuena

soledad adoquinada

que ella va pisando

con los tacones

al otro lado de la calle

Salivas del vacío

sus sombras escurridas

reptan hasta encontrarse

de nuevo

en la esquina

en las paredes

en la fuente

donde aún flota el eco de un beso

Un gato te mira

ahora estás sola

* Daniela Lázaro (Guadalajara, 1993) estudió la Licenciatura en Lengua y Literatura Hispánica en la UNAM. 